University of California, Hastings College of the Law UC Hastings Scholarship Repository

Faculty Scholarship

2008

\title{
Discourse of Disobedience: Law, Political Philosophy, and Trials of Conscientious Objectors
}

Hadar Aviram

UC Hastings College of the Law, aviramh@uchastings.edu

Follow this and additional works at: http://repository.uchastings.edu/faculty_scholarship Part of the Law and Society Commons

\section{Recommended Citation}

Hadar Aviram, Discourse of Disobedience: Law, Political Philosophy, and Trials of Conscientious Objectors, 9 J.L. Soc'y 1 (2008). Available at: http://repository.uchastings.edu/faculty_scholarship/14

This Article is brought to you for free and open access by UC Hastings Scholarship Repository. It has been accepted for inclusion in Faculty Scholarship by an authorized administrator of UC Hastings Scholarship Repository. For more information, please contact marcusc@uchastings.edu. 


\section{Faculty Publications \\ UC Hastings College of the Law Library}

Author: Hadar Aviram

Source: Journal of Law in Society

Citation: $\quad 9$ J.L. Soc'y 1 (2008).

Title: $\quad$ Discourse of Disobedience: Law, Political Philosophy, and Trials of Conscientious Objectors

Originally published in JOURNAL OF LAW IN SOCIETY. This article is reprinted with permission from JOURNAL OF LAW IN SOCIETY and Wayne State University Law School. 


\title{
DISCOURSE OF DISOBEDIENCE: LAW, POLITICAL PHILOSOPHY, AND TRIALS OF CONSCIENTIOUS OBJECTORS
}

\author{
HADAR AVIRAM
}

\begin{abstract}
This Article examines the way legal systems respond to social problems through a discursive analysis of a unique and timely issue: conscientious objection to military service based on political and ideological grounds. It explores how legal systems, conducting criminal justice procedures under conditions of warfare and dissent, attempt to maintain balance between addressing the extra-legal challenges presented to them through conscientious objection, and preserving the prevalence of legal inner logic, classification, and interpretation.

As opposed to the jurisprudential and philosophical literature about conscientious objection, this Article approaches the issue through an empirical analysis of legal and judicial discourse in a particular case study. It follows the fascinating story of the left-wing conscientious objection movement in Israel, following the escalation of the IsraeliPalestinian conflict beginning October 2000. It then examines the two cases that made it to Israeli military courts, analyzing the legal procedures and the verdict language to learn how the legal system chose to construct its perception of the defendants, their actions, and the desired policy.

As the Article claims, while the court seeks to eventually preserve the ethos of military service and to discourage ideological dissent, it also strives to maintain legitimacy for its decisions under heavy media coverage, civilian scrutiny and political unrest. Therefore,

\footnotetext{
* PhD Candidate, Jurisprudence and Social Policy Program, University of California, Berkeley. LL.B., M.A (Crim.) Hebrew University of Jerusalem. I thank Malcolm dissertation, from which this paper stems, as well as to Hila Keren for her helpful comments on the draft and to Noam Finger for his assistance in proof-translations; I am also grateful for the Fulbright Fellowship and Cancellor Dissertation Award which facilitated this project.
} Feeley, Kristin Luker and Neil Fligstein for their useful comments on my doctoral
\end{abstract}


it allows the objectors to bring up extra-legal, political, biographical and philosophical issues, and awards them exceeding procedural flexibility. The eventual verdicts, however, reflect the doctrinal-legal tendency to reduce complex personalities and situations into monolithic, mutually-exclusive categories, to facilitate a workable classification of the offenders for normative purposes.

\section{TABLE OF CONTENTS}

I. Introduction: How Law Thinks about Conscientious Objection

II. Conscientious Objection to Military Service: Theory, Politics, and Legal Doctrine
A. What Is Conscientious Objection? Philosophical
Definitions and Moral Dilemmas
B. The Compulsory and Egalitarian Military Service Ethos: National Heritage, Consensus and Dissent
C. A Socio-Demographic Profile of the Conscientious Objection Movement
D. The Legal Policy Concerning Conscientious Objection
E. The Al Aksa Intifada and the New Wave of Left-Wing Objection

III. The Conscientious Objector Trials

A. Political Dissenters or Mutineers? The Left-Wing Conscientious Objection Movement and "The Five" Case

B. Are You a Good Pacifist or a Bad Pacifist? The Ben Artzi Case

C. Flexibility and Legitimacy

IV. Legal and Extra-Legal Discourse in Conscientious Objector Verdicts
A. Defining the Problem: Highlighting Danger, Downplaying Controversy
B. Understanding the Offenders: "Good" and "Bad" Moral Dissent
C. Using Knowledge: Legal and Extra-Legal Sources for Perceiving the Problem
D. Achieving Goals: Punishing the Offenders and Obtaining Legitimacy
V. Conclusion: Law's Response to Political Dissent: Simplification, Categorization, and Self-Reference 


\section{Introduction: How LaW Thinks About Conscientious OBJECTION}

Political dissent to military service in controversial circumstances, and the way legal systems address it, is a timely and controversial subject linked with several current international conflicts. Recently, CBS News reported of 5,000 deserters from the American forces in Iraq who provide conscientious reasons for their resistance. ${ }^{1}$ Thousands of miles away, the ever-changing realities of the IsraeliPalestinian conflict, most recently in the escalation of the conflict since October of $2000,{ }^{2}$ give rise to political activism and dissent which are partly manifested as movements for conscientious objection to military service. ${ }^{3}$

Both of these legal systems, as well as many other legal systems in different times and places, ${ }^{4}$ face unique challenges when presented

1. Deserters: We Won't Go to Iraq (CBS television broadcast December 9, 2004).

See Charles C. Moskos \& John Whiteclay Chambers, The New Conscientious OBJECTION: From SACRED TO SECUlAR RESISTANCE (Oxford University Press 1993), for other examples of secular, politically-motivated resistance in the American Army in recent conflicts.

2. The most recent of these developments is the Israeli governmental decision to separate from the occupied territories, a move which will include the evacuation of Jewish settlements. See Herb Keinon, Sharon, Mofaz Sign Evacuation Orders, JERUSALEM POST, Feb. 20, 2005, at 1.

3. During the escalation of the conflict, conscientious objection was an exclusively left-wing phenomenon, stemming from objection to serve in the territories and collaborate with the occupation. See Sarah Leibovitz-Dar, The New Frontier of Objection, HA'ARETZ, Dec. 8, 2000. The recent changes in the political situation, described in supra note 2, at 1, albeit supported by many Israelis and Palestinians alike, are giving rise to similar initiatives from religious right-wing soldiers, who object to the evacuation of Biblical Israeli territory. See Israeli Soldiers May Refuse Orders (CBS television broadcast January 3, 2005). Since the latter movement has only just emerged, and has not been yet put to the test of reality and law, this Article analyzes the legal policy toward the former movement.

4. See, e.g, KeIth L. SPRUNGER, VoICES AGAINST WAR: A GUIDE TO THE SCHOWALTER ORAL HISTORY COLLECTION ON WORLD WAR I CONSCIENTIOUS OBJECTION (Rev. ed., Bethel College 1981); SUE KINCHY, PROFILES IN CONSCIENCE: 200 YEARS OF CONSCIENTIOUS OBJECTION IN THE ARMED FORCES (1973). 
with offenders with political and ideological motives, particularly in times of war, which invariably raise moral and humanitarian dilemmas of warfare ethics, as well as a sense of patriotism and concern for national safety. ${ }^{5}$ The legal system may feel the need to uphold laws of compulsory draft, whether permanent or ad hoc, ${ }^{6}$ in order to maintain order and cohesion, if not consensus, in times of unrest; at the same time, it needs to maintain respect, and an open ear, to the moral dilemmas, whether objective or subjective, faced by those whom it judges.

This Article offers a way to understand how legal systems consider conscientious objection from a fresh and unusual perspective. Rather than suggesting philosophical and jurisprudential guidelines for legal policy, ${ }^{7}$ the Article uses a case study - the Israeli military legal system's response to the conscientious objection wave following the $\mathrm{Al}$ Aksa Intifada of 2000 - to enter a legal system's collective mind and examine how it perceives and addresses the phenomenon of conscientious objection; how much of these perceptions are shaped by the political and ideological issues driving the objectors; and how much of them are shaped by law's inner logic and knowledge-production mechanisms. As the case study shows, the legal system is not insensitive to the extra-legal dimensions of the conscientious objection problem, and it allows the objectors significant procedural flexibility, as well as a substantive "voice", in the process. However, for the purpose

5. Moral dilemmas are particularly evident in conflicts that require military personnel to confront civilian populations. See Colm MCKEOGH, InNocent Civilians: The MORALITY OF KILLING IN WAR (Palgrave Macmillan 2002); See also MichaEL WALzer, ARGUING ABout WAR (New ed., Yale University Press 2006).

6. In Israel, military service has been a general duty since the State's inauguration in 1948. See Security Service Act, 1982 (Isr.). See JAMES M. GERHARDT, THE DRAFT AND PUBLIC POLICY: ISSUES IN MILITARY MANPOWER PROCUREMENT, 1945-1970 (Ohio State University Press 1971), for a discussion on how general draft policies shift across time in the United States.

7. Such discussions constitute the backbone of the rich tradition of literature on the subject. See, e.g., Carl Cohen, Civil Disobedience: Conscience, Tactics And THE LAW (Columbia University Press 1971); Carl Cohen, Conscientious Objection, 4 ETHICS 269 (1968); JOHN RAWLS, A THEORY OF JUSTICE (Universal Law Publishing Co. Ltd. 2005), Michael Walzer, The Obligation to Disobey, 77(3) ETHICs 163 (1967). 
of justifying its decisions in conscientious objection cases, the system reduces and simplifies the offenders and their actions into monolithic, mutually exclusive categories, which allow it to apply workable classifications and interpretations using formal legal logic. The Article claims that this duality of flexibility and adherence to legal thought patterns allows the system to reach a politically desirable outcome convicting and punishing the offenders - while awarding it external legitimacy stemming from its fairness and objectivity.

The analytical framework informing the Article's quest into the legal system's mind is Foucault's governmentality theory. ${ }^{8}$ While this framework is applicable to a variety of settings involving policy and knowledge, it is used in this Article to analyze the particular case of criminal justice policy.

Governmentality focuses, analytically and methodologically, on the connection between power - exercised at various levels, from state power to power over the self - and knowledge. ${ }^{9}$ Foucault observes an interplay between:

a 'code' which rules ways of doing things... and a production of true discourses which serve to found, justify and provide reasons and principles for these ways of doing things. To put the matter clearly: my problem is to see how

8. Space precludes a full explanation of Foucault's theory; I therefore present a few of its aspects which are most pertinent for the framework of this paper.

9. The framework was developed by Foucault in his lectures at the College de France See Michel Foucault, Governmentality, in THE FouCAulT EFFECT: STUDIES IN GovernmenTALITY (Graham Burchell, Colin Gordon, \& Peter Miller, eds., University Of Chicago Press 1991), and, less explicitly, in other works, MICHEL Foucault, Discipline and PUNish: The BirTh of THE PRison (Vintage 1995); Michel FouCAUlt, The History OF SEXUAlity, VOLUME I: AN INTRODUCTION (Vintage 1990). However, Foucault's notion of "law" was rather narrow; governmentality developed to encompass the modern concept of law, using Weberian ideas of legal rationality, in later projects drawing on his work. BURCHELL ET AL, ibid ALAN HUNT AND GARY WICKHAM, FOUCAULT AND LAW: TOWARDS A SOCIOLOGY OF LAW AS Governance (Pluto Press 1994); NikOlas Rose, POWERS OF FreEDOM: REFRAMING PolitiCal THOUght (Cambridge University Press 1999). For an analysis comparing Foucauldian theory to other discursive frameworks, see NIELS AKERSTRON ANDERSEN, DisCURSIVE ANALYTICAL STRATEGIES: UNDERSTANDING FOUCAULT, Koselleck, LAClaU, LuHMANN (Policy Pr. 2003). 
men govern (themselves and others) by the production of truth. ${ }^{10}$

The emergence of this "code" and the production of a "truth" which informs and supports it is studied through different events, approaches and practices, emerging in different social locations and fields, to establish the "conditions of possibility" "which constitute ground for the emergence of ideas and policies. Rather than searching for deep structural motivations for policy, governmentality attends to "superficiality, an empiricism of the surface, of identifying the differences in what is said, how it is said, and what allows it to be said and to have an effectivity". ${ }^{12}$ Governmentality is not interested primarily in demonstrating the ideological distortions in official "truth", but in documenting how the investment of power in forms of truth transforms the way subjects and social institutions become problems for government. Governmentality-influenced questions about a given legal policy would be: how does the policy, initiative or program, perceive the problem and the subjects involved in it? What realms of knowledge influence this perception? Which forms of knowledge and expertise allows for the problematization (or, in our case, criminalization) of particular kinds of individual behaviors, or the adoption of a new strategy or policy regarding a certain issue at a certain time and place? What techniques and strategies are promoted as solutions for the problem?

While several works advocate the applicability of governmentality theory to the analysis of legal systems, ${ }^{13}$ none have incorporated it in empirical studies of legal verdict texts, though a very similar, and parallel, enterprise was undertaken by Professor Jonathan Simon in his masterful analysis of the Warren Commission. ${ }^{14}$

10. Ibid. at 90 .

11. Rose, supra note 9 , at 57.

12. Id.

13. BURCHELl ET AL, supra note 9; HUNT AND WICKHAM, supra note 9. 
Analyzing the Commission's report of President Kennedy's murder by Lee Harvey Oswald, Professor Simon highlights the important discursive role of the Commission's report: "to fill the empty space . with a believable explanation; . . . to make sense of what happened." 15 This role is even more important in criminal cases, where what is said in court and written in the verdict needs to constitute a plausible justification for conviction and punishment (or for acquittal).

What is unique about legal cases and judicial decisions is that the justification provided for the outcome of the case must be a legal justification. Criminal justice procedures, decisions, verdicts and sentences are based on legal logic, which consists of identifying the appropriate rule for the specific situation presented to the court and correctly applying it to reach the normative outcome. ${ }^{16}$ This system of logic is self referential: verdicts showing how these rules are applied constitute, in themselves, instructions for the usage of rules on other situations in the future. ${ }^{17}$ The process of applying legal principles to specific situations builds on a classification of the specific case at hand

14. Jonathan Simon, Ghosts of the Disciplinary Machine: Lee Harvey Oswald, Life History, and the Truth of Crime, 10 YALE J.L. \& HUMAN. 75 (1998).

15. Ibid. at 77 .

16. See, e.g., Duncan Kennedy, Legal Education as Training for Hierarchy, in THE Politics of LAW: A Progressive CritiQue (David Kairys, Ed., Basic Books 1998); William TWINING AND DAVID Miers, How to Do ThINGS WITH Rules: A Primer O INTERPRETATION (Butterworths 1999); KENNETH J. VANDEVELDE, THINKING LIKE A Lawyer: An InTroduction to Legal Reasoning (Westview Press 1996). The American legal system relies on jury decisions to establish guilt or innocence, limitin judicial reasoning to decisions in appellate instances; however, in non-jury legal systems, such as the Israeli system, criminal verdicts include not only a statement as to the outcome of the trial, but also a justification for reaching said outcome. In the military justice system, described in this article, the obligation to provide reasoning for verdicts can be found in article 440(9) of the Military Justice Act, 1955 (Isr.).

17. This is the idea behind the doctrine of stare decisis. Some theoreticians, primarily Dworkin, see this doctrine as a manifestation of the constant legal enterprise of interpretation, RONALD DWORKIN, LAW'S EMPIRE (Harvard University Press 1986). Scholarship in the tradition of systems theory refer to this self referential quality of law as "legal autopoiesis": NiKLAS LuHMANN, LAw AS A SocIAL SYSTEM (Oxford University Press 2004); Gunther Teubner, How the Law Thinks: Toward a Constructivist Epistemology of Law, 23(5) LAW \& SOC'Y REV. 727 (1989). 
into legally-prescribed, mutually-exclusive categories, which prescribe a normative outcome according to the category where the case belongs. ${ }^{18}$

However, case hearings and verdicts have additional audiences and purposes: they are read by the parties, appellate judges, academics, and the media, and have to convince these external institutions of their validity and coherence. ${ }^{19}$ A convicting verdict needs to narrate the events in a manner which explains why the defendant's action constitutes a violation of a legal duty; it is followed by a sentence, which needs to explicate the circumstances in a manner that justifies the amount and type of punishment inflicted upon the defendant. Both parts of the decision need to show that the decision was reached in a way which does not violate the principles that provide legal systems with their legitimacy; their claim of objectivity, logic, and impartial implementation of universal principles. ${ }^{20}$

This Article examines the way legal systems shape their processes and decisions to fulfill these complex roles through an analysis of the two conscientious objector cases which reached the Israeli military court in the summer of 2003. The cases are presented through a variety of military and journalistic sources, as well as through interviews with the legal policymakers and representatives of the army and the defendant, and through extensive courtroom observations carried between June and October of 2003.

Part I of the Article provides an introductory overview to the phenomenon of conscientious objection to serve in the Israeli army, placing the problem in context of political philosophy, Israeli reality and military law, and presenting the "conditions of possibility" for the legal policy toward deserters. By showing the philosophical and

18. TWINING, supra note 16; VANDEVELDE, supra note 16; MAX WEBER, ECONOMY AND Society (New Ed., University of California Press 1978); MAX WeBER, CHARISMA AND INSTITUTION BUILDING: SELECTED PAPERS (University of Chicago Press 1968).

19. This is necessary for obtaining legitimacy for the exercise of judicial power: Douglas Hay, Property, Authority and the Criminal law, in AlBION's FATAL TreE: CRIME AND SOCIETY IN EIGHTEENTH CENTURY ENGLAND (Douglas Hay, ed., Pantheon Books 1975).

20. See generally MARTIN SHAPIRO, COURTS: A COMPARATIVE AND POLITICAL ANALYSIS (University of Chicago Press 1986). 
cultural sources for the legal system's perception of conscientious objection, this part provides a "genealogy" of ideas, and explains how the system obtains and constructs its knowledge of the problem.

In Part II, the Article tells the story of the two conscientious objector trials; it describes the political background for their emergence, as well as the legal hearings themselves, emphasizing the manners by which the objectors presented themselves and their ideologies and the ways in which these presentations were perceived and addressed by the system during the trials. The narratives of both cases show the court's willingness to discuss extra-legal issues, such as the offenders' personal biographies and the etiology of their political views, as well as the flexibility it exhibited in shaping the procedural aspects of the trial; this openness and flexibility, the Article argues, provided the court with legitimacy for its decisions.

The court's decisions in the two cases are analyzed in Part III, which shows, through a content analysis of the verdicts and sentences, how the court chose to define the problem and regard the defendants. This chapter examines the court's usage of legal and extra-legal sources of knowledge about the problem and the goals it sought to achieve using these sources and perceptions.

Finally, the conclusion places the analysis in context of the discursive theoretical framework, shows the way the verdict shapes and constructs knowledge about conscientious objection, and offers an explanation of how the verdicts reflect both the court's and the objectors' interests. 


\section{CONSCIENTIOUS ObJeCtion IN ISRAEl: Theory, Politics, AND LEGAL DOCTRINE}

\section{A. What Is Conscientious Objection? Philosophical Definitions and Moral Dilemmas}

A rich literary tradition, both in Anglo-American ${ }^{21}$ and Israeli ${ }^{22}$ literature, addresses the phenomena of conscientious objection, focusing mainly on political and philosophical aspects of the problem, such as the duty to obey the law and the right to disobey it based on conscientious motives. While much of this discussion exceeds the framework of this Article, it is important to point out two concepts from this literature: conscientious objection and civil disobedience. The two concepts provide a philosophical framework for a situation where a person feels unable to follow the law because it conflicts with his or her ethics. Some well known examples for such conflicts may be a reluctance to pay taxes which finance a regime of slavery or racism, or engagement in nonviolent political activity against such a regime. ${ }^{23}$

The definitions of conscientious objection and civil disobedience slightly differ among thinkers, but for the purposes of this project we may adhere to the definition given by Rawls. ${ }^{24}$ Rawls sees the two concepts as exceptions to the prima facie duty to obey the law.

21. For a few notable examples, see COHEN, RAWLS, and Walzer, supra note 7.

22. See, e.g., David Enoch, Some Arguments against Conscientious Objection and Civil Disobedience Refuted, 36(3) ISR. L. REV. 227 (2004); Chaim Gans, The Concept of a Duty to Obey the Law, 17(3) MishPatim 507 (1987); Chaim Gans, Right and Left: Ideological Disobedience in Israel, 36(3) ISR. L. REV. 1(2004); Alon Harel, Unconscionable Objection to Conscientious Objection: Notes on Sagi and Shapira, 36(3) IsR. L. REV. 219 (2004); Barak Medina, Political Disobedience in the IDF: The Scope of the Legal Right of Soldiers to Be Excused from Taking Part in Military Activities in the Occupied Territories, 36(3) ISR. L. REV. 73 (2004); Amir Paz-Fuchs \& Michael Sfard, The Fallacies of Objections to Selective Conscientious Objection, 36(3) ISR. L. REV. 111 (2004); Avi Sagi \& Ron Shapira, Civil Disobedience and Conscientious Objection, 36(3) ISR. L. REV. 181(2004).

23. See Henry David Thoreau, Civil Disobedience and Other Essays (Dover Publications 1993). See also Martin Luther King, Letter from Birmingham Jail (1963)(on file with author).

24. RAWLS, supra note 7, at 363 . 
He refers to civil disobedience as "a public, nonviolent, conscientious yet political act contrary to law usually done with the aim of bringing about a change in the law or policies of the government."25 Rawls states that conscientious objection might somewhat overlap a broad interpretation of civil disobedience ${ }^{26}$ conscientious objection does not require appealing to the sense of justice of the majority, and does not seek common ground, but entails the premise that one's personal conscience - not necessarily political - is at odds with the constitutional order. The two categories are therefore different, but not mutually exclusive.

\section{B. The Compulsory and Egalitarian Military Service Ethos: National Heritage, Consensus, and Dissent}

Addressing the possibility of conscientious objection as an exception to the prima facie duty to obey the law was a particularly problematic issue in the Israeli army. Since the inauguration of the Israeli state, military service has been a national duty, ${ }^{27}$ as well as a seminal social institution, ${ }^{28}$ supported by a captivating ethos of compulsory and egalitarian service.

\section{Id.}

26. Id.

27. See Security Service Act, 1982 (Isr.). The national service duty includes a period of regular service (approximately three years for men and two for women), followed by a lifetime of yearly reserve service determined by one's gender and military specialization. However, see Avishai Margalit \& Moshe Halbertal, Liberalism and the Right to Culture, in MUlTICULTURALISM IN A DEMOCRATIC AND JEWISH STATE (Menachem Maunter, Avi Sagi \& Ronen Shamir, eds., 1998), for a discussion on how some groups are exempted from military service, such as Ultra-Orthodox Jews, Orthodox women and Israeli Arab citizens.

28. This role is mostly constructed around the army's perception as "melting pot" of the Israeli multi-cultural society, YAGIL LEVY, THE OTHER ARMY OF ISRAEL: MATERIALIST MILITARISM IN ISRAEL (2003). Official narratives still refer to the army under the social slogan of "army of the people"; see the IDF official webpage, http://www.idf.il (last visited Dec. 7, 2004). The army is also credited for generating social status and material advantages, BARUCH KIMMERLING, THE INVENTION AND DECLINE OF ISRAELINESS: STATE, SOCIETY AND THE MILITARY (New Ed., University 
This ethos owes its creation to the Israeli formative national heritage, and particularly to the trauma and lessons of the Holocaust. In the new State, formed as a solution to the problem of anti-Semitism and Jewish persecution, "new Jews" - strong, proactive, rooted to the land will defend themselves. The necessity of a formidable Israeli defense shaped the army's image as an essential institution, ${ }^{29}$ constructing objection to serve as dangerous and unpatriotic. ${ }^{30}$

Simultaneously, the lessons of the Second World War and the Holocaust highlighted the importance of the Israeli army's moral worth. The army was presented as following ethical and humane guidelines, ${ }^{31}$ engaging only in "no-choice wars,"32 and maintaining a clear distinction between permissible and impermissible acts of war (such as attacking civilians), through the concept of "cleanliness of arms."33 Claims to the contrary, emerging in the Lebanon war and the first Intifada, are therefore presented as unfounded, and objecting to serve based on supposedly unethical military practices are discounted. ${ }^{34}$

of California Press 2005). Many Israeli politicians often invoke their military backgrounds, IMMANUEL VALD, THE GORDIC KNOT: MYTHS AND DILEMMAS OF NATIONAL SECURITY (1992); even dissenting groups expressing political opinions often lean on military experience and expertise as providing them with the "right," or the legitimacy, to speak of political matters. For an ironic and extreme example, see the extensive use of ranks and military experience in the conscientious objectors' website, http://www.seruv.org.il, (last visited Mar. 2, 2005).

29. Even the army's name - the Israel Defense Forces - communicates this message.

30. See Menachem Finkelstein, Refusal to Serve in the Territories: Decision of the Military Advocate General, 16 ARMY AND L. 713 (2002).

31. In the early 1990 s, these were formulated as the IDF's ethical code. ASA KASHER, MILITARY ETHICS (1996).

32. This overarching narrative is discussed and criticized in recent historical accounts of Israeli wars, proposing instead that the history of armed conflict is a "history of alternatives." Ilan Pappe, The New History of the 1948 War, 3 THEORY AND CRITIQUE 99.

33. KASHER, supra note 31 . The concept of "cleanliness of arms" and the ethical solution of moral dilemmas is thoroughly discussed in Israeli literature: S. YIZHAR, HiRBET Hiz'Aa; THE CAPTIVE (1949).

34. For an overview of this position see Gans, supra note 19. 
Finally, being the army of an immigration country, ${ }^{35}$ great importance was ascribed to egalitarian military service as a mechanism for social coherence and the establishments of shared ideals. ${ }^{36}$ As a "melting-pot" of Israeli society, the army must maintain social strength and a country of immigrants serves together - the army as a mutual and unifying institution. Dissent from this ideal, particularly based on political claims that might cause ideological and social rifts in the army, are therefore seen as a threat.

In light of these narratives as "conditions of possibility," not surprising that the Israeli legal policy limits the extent of its recognition of conscientious objection. In an essential, defensive, ethical and culturally unifying institution, as the army was constructed, ideological objection to serve is perceived as politically dangerous, ethically unsound and socially irresponsible. The rule for exemption does, however, allow for possible exceptions and is based on a distinction between pacifists and politically motivated objections. Whereas declared, coherent and genuine pacifists who object to participate in all warfare, are released from service, but people objecting to selective wars or tasks - a euphemism for politically motivated objections - are not. Consequently, their objection is considered a Refusal to Obey Orders, an offense under article 122 of the Military Justice Act of $1955 .^{38}$ According to article 122, soldiers must obey all orders (interpreted to include, first and foremost, the initial order to enlist when called for) unless, as article 124 states, "it is clear and obvious that the order given to [them] was illegal."39

35. Israel, designed to be a national home for Jews from all countries, provides citizenship to all immigrating Jews: The LAW OF RETURN, 1950.

36. THOREAU, supra note 23.

37. See supra note 11 and the accompanying text.

38. See Gans, supra note 22; LEON SHELEFF, THE VOICE OF HONOR - CONSCIENTIOUS OBJECTION OUT OF CIVIC LOYALTY (1987).

39. In fact, a soldier obeying a "clearly and obviously" illegal command could be prosecuted for participating in an illegal act; a "clearly and obviously" illegal command was defined, in the infamous Kfar Kasem massacre case of 1956, as a command "bearing a black flag" of illegality: "not formal, hidden or half hidden 
The army and its legal system had to address conscientious objection, based on pacifism as well as political reasons, ever since the $1950 \mathrm{~s}$, and objection to the occupation of the territories began as early as the $1970 \mathrm{~s} .{ }^{40}$ However, the first organized group of objectors emerged during the 1982 war in Lebanon, as part of the left wing "Yesh Gvul" movement. "Yesh Gvul," translated "there is a limit" in Hebrew, advocated "selective" refusal according to the third distinction mentioned above: the objectors refused to serve in Lebanon or in Lebanon-related activities. ${ }^{41}$ The concept of selective refusal was later adopted in the 1988 Intifada to service in the territories, through some of the objectors refused to serve in the army altogether during this time. The Intifada refusal movement led to an increase in the size of overt objection. $^{42}$

The objection to the two wars had a common rationale. The Israeli army had always declared itself a defensive, protective force, rather than an aggressor; hence its name, "Israel Defense Force." The warfare ethos upon which generations of Jewish Israelis had been raised was based on the premise that all Arab-Israeli wars had been "wars of no choice." 43 The Lebanon war, taking place on foreign soil, and the Intifada encounters with enraged civilian population under occupation, defied these traditional boundaries, and therefore created a "limit," or a boundary, for the objectors. In addition, several Intifada objectors invoked the legal defense for disobeying "clearly and obviously illegal

illegality ... an illegality that stings the eye and enrages the heart, if the eye is not blind and the heart is not obtuse or corrupted": CA 3/57, The Military Prosecutor v. Malinki (1957) PM 17, 90.

40. See Gans, supra note 38; PERETZ KIDRON, REFUSENIK! ISRAEL's SOLDIERS OF CONSCIENCE (State University Press 1996); RUTH LINN, CONSCIENCE AT WAR: THE ISRAELI SOLDIER AS A MORAL CRITIC (State University of New York Press 1996).

41. KIDRON, Ibid; LINN, Ibid.

42. See Ruth Linn, When the Individual Soldier Says 'No' to War: A Look at Selective Refusal During the Intifada, 33(4) J. PEACE RES. 14 (1996).

43. This premise is challenged in recent years, and many wars presented earlier as "wars of no choice" are now said by some scholars to represent a "history of alternatives", in which Israel had engaged in an aggressive role by choice: LEVY, supra note 28; Pappe, supra note 32. 
commands," claiming that participating in the occupation fit into this category.

\section{A Socio-Demographic Profile of the Conscientious Objection Movement}

Although the different waves of objectors varied somewhat over time, they shared several political and socio-demographic characteristics. Ideologically, while some individuals were exempted from service based on their pacifist beliefs, the critical mass of organized conscientious objection has been identified with the left-wing end of the Israeli political map. ${ }^{44}$ The involvement of conscientious objectors in political activism increased over time; whereas the 1982 objectors to the war in Lebanon engaged in demonstrations against the war, the 1988 objectors to service in the occupied territories were more immersed in politically-oriented activities. The Intifada objectors, who had already enjoyed the infrastructure of the Lebanon anti-war movement, were more organized, and involved in political activism in their civilian lives. ${ }^{45}$ The new wave of objectors, brought about by the $2000 \mathrm{Al}$-Aksa Intifada, also supported left-wing views; however, in their official petitions published in Israeli periodicals ${ }^{46}$ they also emphasized their identities as combat officers and soldiers, probably to gain legitimacy in the eyes of more militant, less left-wing groups in Israeli society. ${ }^{47}$

The new wave of objectors, brought about by the 2000 Al-Aksa Intifada, also supported left-wing views; however, in their official petitions published in Israeli periodicals ${ }^{48}$ they also emphasized their identities an combat officers and soldiers, probably to gain legitimacy

44. See Gans, supra note 22 . This trait, however, may change in light of the recent political development: see supra note 3 and the accompanying text.

45. See LINN, supra note 41; Linn, supra note 42.

46. See Petition, HA'ARETZ, December 1, 2002.

47. Aviv Lavi, We Have Sobered Up, HA'ARETZ, Dec. 27, 2002.

48. Petition, HA'ARETZ, December 1, 2002. 
in the eyes of more militant, less left-wing groups in Israeli society. ${ }^{49}$ This is evident from their usage of military uniforms and ranks in the textual and graphic content of their website, as well as from the petition itself:

- We, reserve combat officers and soldiers of the Israel Defense Forces, who were raised upon the principles of Zionism, sacrifice and giving to the people of Israel and to the State of Israel, who have always served in the front lines, and who were the first to carry out any mission, light or heavy, in order to protect the State of Israel and strengthen it.

- We, combat officers and soldiers who have served the State of Israel for long weeks every year, in spite of the dear cost to our personal lives, have been on reserve duty all over the Occupied Territories, and were issued commands and directives that had nothing to do with the security of our country, and that had the sole purpose of perpetuating our control over the Palestinian people. We, whose eyes have seen the bloody toll this Occupation exacts from both sides.

- We, who sensed how the commands issued to us in the Territories, destroy all the values we had absorbed while growing up in this country.

- We, who understand now that the price of Occupation is the loss of IDF?s human character and the corruption of the entire Israeli society.

- We, who know that the Territories are not Israel, and that all settlements are bound to be evacuated in the end.

- We hereby declare that we shall not continue to fight this War of the Settlements.

- We shall not continue to fight beyond the 1967 borders in order to dominate, expel, starve and humiliate an entire people.

- We hereby declare that we shall continue serving in the Israel Defense Forces in any mission that serves Israel's defense.

49. Aviv Lavi, We Have Sobered Up, Ha'aretz, Dec. 27, 2002. 
- The missions of occupation and oppression do not serve this purpose - and we shall take no part in them. ${ }^{50}$

Although the conscientious objection movement is motivated by, and ostensibly organized around, political views, some suggest that the bond between members consist as much of social milieu as of ideology. ${ }^{51}$ Conscientious objectors from the 1982 Lebanon war and the 1988 Intifada have been identified as being primarily middle-class and of Western (Ashkenazi) ethnicity. ${ }^{52}$ In some of the literature, the objectors themselves prefer to present themselves as more diverse in terms of social background; ${ }^{53}$ however, in other studies their selfdescriptions reveal their more affluent backgrounds and connection with Israeli academia. In a study examining the prison experiences of reservists who were punished for conscientious objection to serve in the territories, one of the interviewees provided the following profile of a typical objector:

$[\mathrm{H}]$ igh or middle class, Ashkenazi, free occupations, a higher percentage of academic background. The majority from the center of the country, the center in Tel Aviv University, high percentage of social sciences, doctoral students, I know the ones that are active in the

50. A Combatant's Letter, http://www.seruv.org.il/ (click on "to the English edition" in the upper left corner; then click on "combatants letter" in the top bar).

51. LEVY, supra note 28 . Levy connects between the social characteristics pointing to the demilitarization of the elites, comprised of secular males of European ("Ashkenazi") ethnicity; according to his analysis, since the Yom Kippur war of 1973, the social capital stemming from military and combat service has gradually eroded, leading the elites to gain prestige through alternative vehicles such as technology, and leaving military service as an arena for the social mobilization of less advantaged groups, such as orthodox Jews, women, and people of Middle-Eastern and NorthAfrican ("Mizrachi") ethnicity.

52. LINN, supra note 42.

53. See KIDRON, supra note 41. 
movement, but wouldn't be surprised if this is the general profile. ${ }^{54}$

In a collection of interviews focusing on the conscientious objectors' political perspectives, ${ }^{55}$ most interviewees describe their socio-economic status as "affluent" or "middle-class". Only one of the interviewees is a Jew of Eastern ethnicity; the others claim that they had not been "privileged" in any special way because of their identity as Westerners. Several of them correlate their acts with social, as well as political, agendas; and one introspective objector observes that the movement was comprised of intellectual-elitists because people who grew up with a sense of entitlement from the consensus would feel more comfortable breaking from it. ${ }^{56}$ Even the Eastern-identified interviewee states that his identity was not shaped to a great extent by his ethnicity, which he now claims to regret. The younger objectors describe politically active families, often comprised of members of the Israeli intellectual elite.

In summary, the conscientious objectors appear to enjoy a variety of social resources, stemming from both their strong political conviction (and, subsequently, strong organization and mutual support) and social status (reflected by their confidence, eloquence, and strong support from capable families). The following subparts illustrate how influential this ideological and demographic background was in their encounters with the law.

\section{The Legal Policy Concerning Conscientious Objection}

This rule according to which pacifism merits an exemption from military service while politically-related refusal to serve

54. HADAR AVIRAM, When the Saints Go Marching In: Legal Consciousness and Prison Experiences of Conscientious Objectors to Military Service in Israel, in THE NEW CIVIL RIGHTS RESEARCH 183, 195 (Laura Beth Nielsen \& Benjamin FleurySteiner, eds., Ashgate Publishing 2006.)

55. See Ronit Chacham, Breaking Ranks: Refusing to SERve In the West Bank AND GAZA STRIP (Robert Hack, ed., Other Press 2003) (2003).

$56 \mathrm{Ibid}$. at 53. 
constitutes a criminal offense was rather complex to uphold in the 1982 and 1988 waves of conscientious objection. Many commanders were open to informal negotiations of alternative service with their refusing soldiers, or turned a blind eye to reserve solders who left the army based on medical, or mental health, reasons, or moved abroad. Others treated their soldiers more harshly, by sending them to prison and expelling them from their units. ${ }^{57}$

This informal treatment became somewhat more formalized in 1995, when the Chief of Personnel formed a special committee (known by the soldiers as the "conscience committee"). The actual circumstances behind forming the committee are unclear. Military prosecutors claim that it was an institutional move to better organize the policy for exempting personnel based on conscience and ideology. However, defense attorneys, as well as critical literature, allege that the committee might have been formed to anticipate a potential wave of refusals from religious right-wing soldiers in the event of settlement evacuation. ${ }^{58}$

The committee's formation was not publicly announced, nor has its function been regulated in any act of legislation or paperwork. ${ }^{59}$ The unwritten guidelines for the committee's function maintain the status quo preceding its existence: pacifists - defined for legal purposes as people who object to any type of service in any type of armed force - were exempted, whereas "selective objectors" those who rule out participation in an armed conflict only in certain circumstances - were not. ${ }^{60}$ The committee did not have authority to make final decisions, but only to recommend an outcome to the Chief of Personnel Unit. However, the committee's recommendations were invariably affirmed by the official decision.

57. LiNN, supra note 40 at 426.

58. Based on interviews with military prosecutors and defense attorneys (on file with author). Also see LEVY, supra note 28.

59. The information about the committee's members and informal guidelines, therefore, is obtained from the Ben Artzi petition to the High Court of Justice: HC 1380/02 Ben Artzi v. the Minister of Security (2002), PD 56(4), 76. (henceforth referred to as the Ben Artzi Petition), as well as from newspaper reports: Tal Hassin, $A$ Trojan Horse in the Conscience Committee, Ha'aretz, July 18, 2003.

60. Hassin, id; See also Ben Artzi Petition, supra note 56. 
The committee is chaired by an officer from the Personnel unit and includes a legal representative from the Military Attorney General Unit (the Consultation and Legislation branch, which deals with civilian affairs), as well as members of regulation and behavioral science units. Until the High Court of Justice recommendation that a civilian be appointed to the committee, made in the Ben Artzi Petition, ${ }^{61}$ it was comprised exclusively of military members. Following the petition, the army began appointing a civilian member to the committee. This member is invariably a volunteering philosophy professor - a choice which reveals the army's conformity to the dominant discourse on conscientious objection, and yet a peculiar one considering the self-described objective of the committee $-\mathbf{a}$ tool for finding out whether the applicants in question are honest in their claims of pacifism. ${ }^{62}$

Throughout its existence between 1995 and 2003, the committee heard 301 petitions for exemption from service, rejecting $245(81 \%)$ of them, and exempting from service only $24(8 \%)$. In the remaining 32 cases $(11 \%)$ the committee recommended "eased service conditions." ${ }^{63}$ According to the prosecutor, this last option is a bona fide military attempt to accommodate the needs of soldiers who do not have a problem belonging to an armed force, but express other personal limitations, such as a reluctance to bear arms themselves. ${ }^{64}$ Among the options offered to this group is, for example, the possibility to serve in a civilian hospital.

The applicants are allowed legal representation, and may bring with them any written material they choose, as well as two witnesses,

\section{Ben Artzi Petition, Id.}

62. This purpose was described by the committee chair in Ben Artzi's military trial: Headquarters 129/03 (henceforth: the Ben Artzi case/verdict/sentence). See also Hassin, supra note 56.

63. Data obtained from the prosecutor in the two conscientious objector cases (on file with author).

64. This type of selective objection (as opposed to a politically motivated objection) is better tolerated by the army, perhaps due to its individual nature and the fact that, being a unique individual objection, it does not constitute a threat to the ethos of compulsory and egalitarian military service. 
to support their claim of genuine pacifism. The attorney, however, is only allowed in the room before and after the actual process: the applicant is interviewed alone by the committee, and so are the witnesses. $^{65}$

Any attempt to officially regulate military policy regarding conscientious objection beyond the establishment of the committee has been, so far, in vain. Several legislation initiatives sought to legalize conscientious objection by allowing for any person claiming conscientious reasons to be exempted from service. All initiatives, the last of which was made in 1999, failed; the initiatives were strongly opposed by the government and by the army. The Military Attorney General's unit reasoned that allowing a general exemption would practically make military service non-compulsory, and was therefore categorically rejected. ${ }^{66}$

\section{E. The Al Aksa Intifada and the New Wave of Left-Wing Objection}

This was how matters stood when the Israeli-Palestinian conflict escalated into a second Intifada in October 2000. The reoccupation of Gaza and the West Bank in $2002{ }^{67}$ brought about a "new objection frontier" of reservist soldiers, called The Courage to Refuse movement. ${ }^{68}$ Beginning December 2002, the movement published a petition declaring the members' intention not to perform reserve service in the occupied territories. ${ }^{69}$ Throughout the subsequent months, which involved an escalation of the conflict in the territories, many of the objectors who had signed the petition were called for service, refused to attend, and were subsequently tried in disciplinary hearings and sent to short imprisonment sentences. The

65. Ben Artzi Petition, supra note 56.

66. CONSUlTING AND LEGISLATION BRANCH, doc. 35(20) (internal military document; on file with author).

67. BBC News, (BBC television broadcast April 4, 2002).

68. Leibovitz-Dar, supra note 3.

69. A Combatant's Letter, supra note 48. 
reservist objectors' attempt to contest their disciplinary conviction and request a formal criminal trial in court failed; the Military Advocate General refused to grant them a trial, repeating the policy according to which politically-motivated objectors are not exempted from service, and stating that the army's activities in the territories were legal. ${ }^{70}$ His decision was affirmed by the High Court of Justice. ${ }^{11}$ Subsequently, about 250 out of the 635 soldiers who signed the petition were tried in disciplinary hearings and served short imprisonment terms in military facilities. ${ }^{72}$ None of these reservist cases ever reached the military courts.

The reservist movement was soon supplemented by a movement of potential regular-service soldiers. During the summer of 2002 , about 300 draft-age high-school students signed letters addressed to the IDF Chief of Staff, protesting the occupation and declaring their intention to object to service. ${ }^{73}$ As opposed to the reservists who had only refused to serve in the occupied territories, this younger group refused to serve anywhere in the IDF, explaining that every role or position in the army would be assisting, directly or indirectly, the occupation. Some of them stated their refusal upon their arrival to the drafting office on their conscription day; others sent letters beforehand. The army screened the different petitioners based on their own declarations. Only those whose motives seemed ambiguous and might have constituted pacifism were summoned to the conscience committee; those who expressed clear political motives were not summoned for a hearing. ${ }^{74}$

70. FINKELSTEIN, supra note 30.

71. HC 7622/02, Zonshein et al v. The Military Advocate General (2002), PD 57(1) 726.

72. http://www.seruv.org.il (click on "English" link in the upper left, and then click on "about us"). See also Aviram, supra note 52.

73. For a retrospective about the letter, see http://www.newprofile.org/showdata.asp?pid=144. Some of these groups were related to the youth groups of the "New Profile" movement, an organization aimed at demilitarizing Israeli society.

74. Headquarters 151, 174, 205, 222, 243/03 Military Prosecutor v. Matar (2003); excerpt published in: THE REFUSENIKS TRIALS (eds: Dov Khanin, Michael Sfard, 
Military personnel documents obtained from the prosecutor show that the army was closely following each and every case of objection. A special personnel document ${ }^{75}$ contains a list of objectors and their military data (medical and psychometric exam results), and refers to the proceedings in committees and disciplinary hearings in their matters. In several cases, the objectors were awarded exemptions from service for reasons related to narcotics and other personal issues, which were "neutral," non-conscientious grounds. A few people are listed as "agreed to serve" (the circumstances are not noted) and some of them are "scheduled for a meeting with parent" and military officials. This systematic monitoring of individuals reflects the military regard of each of the 300 or so high-school students as an individual challenge.

The personal attention to each of the objectors was also evident in the way the army initially dealt with them, which reflects the army's commitment to the ethos by which "everyone can serve." In the height of the refusal movement, the army was prepared to offer service options to match the soldiers' needs (like the abovementioned "eased service conditions"), as long as these did not clash with the needs of the system. ${ }^{76}$ The degree to which this tendency was beyond what would be awarded to a regular soldier with problems was left unclear.

\section{The CONSCIENTIOUS ObJECTOR TRIALS OF 2003}

\section{A. Political Dissenters or Mutineers? The Left-Wing Conscientious Objection Movement and "The Five" Case}

While some of the military "problems" with conscientious objection were solved through disciplinary hearings and back-door exemptions from service, some objectors were more persistent. Five

Sharon Rotbard) (2004), 205 (henceforth referred to as "The Five" case). (page numbers refer to the unpublished original courtroom record).

75. Military Personnel Unit, Report on Draft Refusers - Conscience $(I D F, 2003)$.

76. Interview with the prosecutor in the conscientious objector cases (on file with author). 
of the regular service objectors had repeatedly refused to enlist and could not be quietly accommodated otherwise. Three of them were not summoned by the Conscience Committee, as their actions and motivations demonstrated clearly that they were not pacifists, and therefore would not be exempted based on the current policies. After several repeated disciplinary hearings, and according to a reportedly new, harsher, prosecution policy, ${ }^{77}$ the five objectors were finally tried together for Refusal to Obey Orders. ${ }^{78}$ All five retained the same attorney, Dr. Dov Khanin, a prominent jurist with a political background in the radical socialist political party "Hadash." The military prosecution chose Captain Yaron Kostelitz, a young and promising member of the Chief Military Prosecutor's office, to handle all affairs pertaining to conscientious objectors. ${ }^{79}$ Kostelitz, an Orthodox Jew, was reportedly chosen for this task not only for his formidable professional talents, but also "because we needed someone that would be convinced of his righteousness and without any conflict about the case. ${ }^{, 80}$ The main defense argument claimed the existence of a "right to conscience" as a basic right and a legal defense against the indictment.

After the objectors were arrested, and following a consultation in court in which the prosecution's agreement was obtained, they were released to "open detention," enabling them relative freedom and the ability to appear for the hearings uncuffed. ${ }^{81}$ While in "open

77. Arye Dayan, Refusing for the Sixth Time? You'll Be Court-Martialled, HA'ARETZ, 2003.

78. Military Justice Act, Article 122 (1955) (Isr.).

79. In interviews with me, both the prosecutor and his commanders mentioned the parties' representatives' personal backgrounds as pertinent to the trial (transcriptions are on file with author).

80. Interview with the Chief Military Prosecutor (on file with author).

81. "Open detention" is a unique military version of bail conditions. The soldiers are not held in custody; instead, they are assigned duties in military units and subjected to their authority. Under "open detention", a soldier is subjected to much easier and milder conditions than in a custodial or correctional military facility. The drawback for many soldiers is, however, the fact that "open detention" time is not deducted from the term of imprisonment, if such a sentence is imposed. 
detention" the defendants wore uniforms but they appeared in court in civilian clothes. ${ }^{82}$ The prosecutor, with little encouragement from the court, did not officially insist on military attire and the court, intent on providing as much "space" and fairness to the defendants, and careful not to appear as an arbitrary military tribunal, did not demand it. This allowed the defendants a symbolic victory, in the sense that in their public appearances, as opposed to their hidden detention duties, they did not submit to the military apparatus. ${ }^{83}$

The trial began in March 2003 and ended with a convicting verdict on December $16^{\text {th }}$ and a prison sentence in early February 2004. Each stage of the process was contested by the objectors. The defense attorney attempted to dismiss the indictment claiming that the law discriminated against the defendants, all male, by allowing women the possibility of exemption based on conscientious motives ${ }^{84}$ and also claimed that the flaws in the conscience committee's work amounted to an "outrageous injustice" that required refraining from trying the defendants. These claims, as well as a lack of jurisdiction claim, were categorically rejected by the military court. The court referred to the release of women as a mistake, but one that did not amount, even with the addition of other flaws, to such an "outrage" that would justify dismissing the indictment.

Following the opening speeches in April, the defendants were finally heard on June $23^{\text {rd }}$ and July $14^{\text {th }}$. The five objectors were directexamined one by one and only following all direct examinations were

82. Courtroom observations, June-September 2003 (field notes are on file with author).

83. The attire issue was eventually introduced into the trial in the prosecutor's summary. The prosecution's claims that the defendants were not "genuine" moral objectors, but civil mutinees with political aims, were supported by the fact that they had no moral objection to wearing uniforms within the unit. Although this claim was rejected by the court in the final verdict, it upset the defense counsel and the audience, and brought about harsh word exchanges and commotion in the courtroom. In this manner, the physical fact of clothing was translated to the legal vocabulary as a representation of submission, or non-submission, to legal status.

84. Security Service Act, Article 36 (1982) (Isr.); the article has since been narrowly reinterpreted by the Israeli Supreme Court to exempt women from service only based on religious and ethnic grounds. 
cross-examined by the prosecutor in the same order. ${ }^{85}$ In this manner, the "five" were treated as a group, and their testimonies were regarded as five parts of the same testimony for procedural purposes. This arrangement benefited the defendants because it allowed them to present their full versions in direct examination, before being crossexamined; it also presented them to the court and the audience not as five separate people but as a united front. The court allowed the defendants ample time to present their versions; the direct testimonies took about two to four hours each. Every defendant chose to approach the testimony in a different manner; some told their personal histories and how those had led them to oppose the occupation by refusing to serve. Some gave more general treatises about Israel's policy in the territories. ${ }^{86}$ Although the court did not rule on the legality of the occupation, ${ }^{87}$ it did allow the defendants to speak extensively about the matter. This strategy of providing nearly unlimited "voice" to the defendants benefited both parties to the trial. On one hand, in the symbolic level, the defendants could present their versions to the court in a coherent, organized, full manner, standing cross-examination only after all defendants had been heard at length. This testimony style was later hailed in left-wing publications, who praised the lucid, thoughtful, and well articulated manifestos of the defendants. ${ }^{88}$ On the other hand, this method also allowed the prosecutor to get a better impression of the general argument and to organize the cross-examination accordingly.

The direct examinations on July $14^{\text {th }}$ were interrupted by the testimony of the Draft Bureau commander as to the act of refusal. This witness was declared hostile by the defense and cross-examined about the lack of thorough treatment and complete regulations in the matter of conscientious objection. Following his testimony, the direct testimonies

85. My description of the proceedings is based on my courtroom observations, carried between June and September of 2003. Changing the order of direct and cross examinations is not illegal, but is extremely unusual: Military Justice Act, supra at note 75 .

86. The full text of the testimonies has been since compiled in THE REFUSENIKS TRIALS (Supra note 74).

87. Supra note 74.

88. KIDRON, supra note 35; KHANIN, supra note 74. 
of the five defendants continued on the same day. The September $18^{\text {th }}$ and October $20^{\text {th }}$ meetings included cross-examination of the defendants, followed by extensive oral and written summations from the prosecution and defense throughout November.

The court's verdict was delivered on December $16^{\text {th }}$. The court decided to convict the defendants, and it ruled that the current policy, distinguishing between pacifists and political objectors, was constitutionally sound. In addition, the court's impression of the defendants was not of personal morality motivated people, but of political instigators. ${ }^{89}$ An appeal was submitted in the defendants' name, but later retracted, according to the media out of a conviction that they "would not receive a fair trial" in the Military Court of Appeals.

The sentencing hearing on December $23^{\text {rd }}$ revealed the difference in opinion about the suitable punishment for the objectors. The prosecutor's summation referred to the objectors as "ideological criminals" and argued that they were more dangerous than "ordinary criminals" but the defense attorney thought their honesty and idealism merited great leniency. One judge voted for a 20 -month punishment, one for a year-long sentence, and one for merely six months of imprisonment. According to military criminal procedure, the middle judge's opinion was accepted. ${ }^{90}$

On February $17^{\text {th }}$, weeks after the five were sentenced to imprisonment, a hearing was conducted to determine whether they would remain in the military facility or be transferred to a civilian prison. ${ }^{91}$ The military prison services wished to transfer the five but the prisoners objected, asking to remain in military custody. The final decision of the committee stated that the parties had agreed that the

89. Matar, supra note 71.

90. Military Justice Act, 1955 (Isr.).

91. This is standard procedure, sanctioned by Article 210 of the Military Justice Act. Military correctional facilities do not have any rehabilitative, vocational, or educational programs, and are therefore not suitable for long-term prisoners: On the other hand, for some soldiers, the encounter with the civilian prison population can be traumatic. Therefore, every defendant sentenced to more than one year of imprisonment is brought before a special committee, which decides on the appropriate facility for the inmate's sentence. 
defendants be transferred to civilian custody. Apparently, after much deliberation between the committee members (in which no unanimous solution was reached) they were notified by the five's legal representative of removing their objection to the transfer. This consensus, reads the decision, rendered the committee's deliberation unnecessary. It is hinted, though, that the five felt the army was "threatened by them." representative tells a somewhat different story, according to which in the hearing the prison representative had indicated his intent to "place the prisoners under a moral dilemma" and "send them for coercive labor in the territories." This message had led them to remove their objection to the transfer. ${ }^{93}$

While the five defendants were serving their imprisonment terms in different civilian facilities, and anticipating their early release hearing, ${ }^{94}$ their parents started a website ${ }^{95}$ in which they requested funding for the parole hearings. The parental effort on behalf of the five included a "documentary reading theater," performed in Tel Aviv early June 2004. The play featured dramatized readings from the trial records. The defense attorney, Dov Khanin, was scheduled to appear as himself in the play. ${ }^{96}$

92. Decision of Committee for Inmate Transferral ('210 Committee') re Hagay Matar and Others (IDF, Feb. 17, 2004) (confidential corrections document; on file with author).

93. Announcement on behalf of the Inmates, submitted to the COMMITTEE FOR INMATE TRANSFERRAL (Feb. 17, 2004) (confidential court document; on file with author).

94. Hadar Aviram, 'And Justice for All?' Regarding the Danger of Generalizing from Exceptional Cases, Following the Rami Dotan Petition, 13 ARMY AND LAW 363 (2001). Officially, early release is available halfway through the sentence, however, following the verdict in the Rami Dotan case such early release is rare, and it is more common to be released after serving about two thirds of the sentence. This policy was criticized, but upheld in the Supreme Court.

95.

http://site234.webhost4life.com/refuz/Default.aspx?alias=site234.webhost4life.com/re fuz/english.

96. Play program, 2004. 
In addition, the defense attorneys of "the five" and Yoni Ben Arzti (see below) co-edited and published an anthology of court documents from both cases, including the defendants' testimonies, written and oral summations by the parties, and the court's verdicts. ${ }^{97}$

On July 15 th, the parole board decided to shorten the five objectors' prison sentences by a third. September 15 th was established as their release date. While this was a standard parole release, it had two unusual features. First, contrary to the prosecution's request, and contrary to the standard requirement for parolees, "the five" were not required to express remorse as a condition for their release. Second, the committee recommended bringing all of "the five" before a military unsuitability committee in order to allow for their release from service.

\section{B. Are You a Good Pacifist or a Bad Pacifist? The Ben Artzi Case}

Concurrent to the "five" case, a separate military trial was being held for another conscientious objector, Yoni Ben Artzi. Ben Artzi's case was tried separately because it brought up different doctrinal questions. Like some of "the five," Ben Artzi had requested a hearing before the conscience committee prior to being drafted. However, unlike "the five," he did not merely claim to have left-wing political views but stated that he was a pacifist and objected to engaging in any form of military activity. The committee was not convinced that his mind was fully made up, and he was ordered to take a year and "solidify his opinion" in the matter of military service. The following year, Ben Artzi appeared again before the committee, which acknowledged that his mind was more "solidly made up" about his refusal to enlist. The Committee decided that he was not a genuine pacifist and would not be exempted from service. The committee stressed that Ben Artzi's issues with the army related more to his leftwing views and to his inability to adjust to coercive institutions and frameworks. ${ }^{98}$

\section{KHANIN, supra note 74.}

98. The history of the case was documented in both the Ben Artzi petition and in Headquarters 129/03 the Military Prosecutor v. Ben Artzi (2003), excerpt published in: KHANIN, supra note 74, 333 (henceforth referred to as "the Ben Artzi case") (page numbers refer to the full, official, unpublished verdict). 
Ben Artzi certainly did not accept this decision quietly. He submitted a petition for its reversal to the High Court of Justice ${ }^{99}$ In his petition he raised a list of procedural flaws in the Conscience Committee's hearing, such as the lack of legal representation and the impossibility to bring witnesses. The court held in his favor and pressed the military authorities into a compromise which entitled Ben Artzi to a third appearance before the committee. This time he was represented by an attorney; submitted an abundance of written material - including letters from his siblings, both graduate students in the US; and produced two witnesses: his parents. For the third time, the committee rejected Ben Artzi's request for exemption, and expressed its view that political convictions and personal maladjustments were at the core of his request.

Snippets of the dialogue in the committee hearings were presented later at the military trial and indicated a problematic and misinformed approach to the issue, at best. Apparently, the committee members had shown Ben Artzi headlines from daily newspapers reports about suicide bombings to confront him with the immorality of refusal under such circumstances. They also argued that his refusal stems from his unwillingness to accept authority, which reflected a far from pacifist personality. ${ }^{100}$ Incidents from Ben Artzi's school days one in which he refused to wear a kippa ${ }^{101}$ to a military cemetery on Remembrance Day, and another in which he did not participate in a school-organized bus ride to a demonstration to support the Supreme Court - were interpreted to illustrate nonconformism and an unwillingness to adjust to coercive frameworks such as school or the

99. HC 1380/02 Ben Artzi v. The Minister of Security, PD 56(4), 76.

100. Trial transcript (excerpted in KHANIN, supra note 74; this work refers to the full, unpublished transcript); courtroom observations (field notes, on file with author). One member referred to the Hebrew word for violence ("alimut") and told Ben Artzi it meant "no conflict" ("al-imut"; the two expressions do not share a common linguistic source; moreover, the linguistic example alludes exactly to the opposite). This fallacious word game was meant to tell Ben Artzi that his various instances of disagreement and protest in the course of his high school studies demonstrated that he was not really a pacifist at heart.

101. Yarmulke, a Jewish headcover for men that is customarily worn even by secular men in cemeteries and funerals. 
army. In addition, Ben Artzi was asked whether he would have fought the Nazis in World War II. This question, highly problematic in Israel because of the Holocaust context, puts those subjected to it in a difficult position: if they answer in the affirmative, they would not be regarded as pacifists. If they answer in the negative, they would be regarded as having very questionable morality. ${ }^{102}$

An additional complication was Ben Artzi's activism in support of, and with, politically-motivated objectors such as "the five." In the Committee's view, his association with left-wing protesters and the leftist opinions in his immediate family ${ }^{103}$ obscured the "purity" of his pacifist agenda.

Following the committee's decision, Ben Artzi was ordered to enlist in the army. Since August 2000 he refused the draft seven times, each time led to a disciplinary hearing and a prison sentence. These sentences amounted to over 200 days in prison. Ben Artzi was indicted in military court when he refused the draft for the eighth time.

At this trial the parties gave their opening speeches and testimony was heard. Michael Sfard, a young attorney at a wellknown law office and a conscientious objector himself, presented the defense's case. He argued the defendant was not guilty of "refusal to obey orders" because he was a genuine pacifist, a fact which the committee failed to recognize due to its flawed and unregulated procedures. The defense made considerable efforts in presenting various aspects of this argument. To prove Ben Artzi's genuine pacifism, the defense presented testimony from him and his sister. To address the committee's arbitrariness and flawed procedure, the defense asked the court's permission to summon for testimony two high-ranked officers, including the Conscience Committee Chair. The prosecutor objected to this move, claiming that the committee's work

102. Trial transcript; courtroom observations (supra note 100).

103. Ben Artzi and his parents were frequently portrayed in the Israeli media as leftwing radicals, and juxtaposed to his uncle and aunt, former Prime Minister Benjamin Netanyahu and his wife Sarah, often referred to in media coverage of the case: HADAR AVIRAM, LAW AND SOCIETY ASSOCIATION ANNUAL MEETING: REFleCTIONS OF DisOBEDIENCE: POWER, IDEOLOGY, AND THE CONSTRUCTION OF RESISTANCE TO MILITARY SERVICE IN ISRAELI MEDIA (2004). 
had already been scrutinized by the High Court of Justice and did not need to be discussed any further. The court, however, moved to allow for both testimonies, stating that they do so beyond their due process obligations and as a courtesy to the defendant:

The defendant was brought to justice before a military court for not doing an action which he claims is against his conscience. In many ways, there is no little uniqueness in our trial... in this stage, when the defendant defends himself with the few tools given to him by criminal law, we think that we should minimize using the court's authority to block the defendant's path from trying to make us doubt, using a tool or this or that legal construction, that he might not have committed the offense attributed to him. ${ }^{104}$

The court's meeting on June $22^{\text {nd }}$ included the testimony of Ben Artzi's sister. She was cross-examined about media reports regarding her brother's leftist views; the sister maintained that her brother's political views were to be separated from his pacifist views. The court also heard the testimony of an objector whose views were similar to Ben Artzi's and who was nevertheless released from service.

The July 29th court meeting was to be a pivotal date in the trial's development. After a long examination by the defense, the Conscience Committee chair admitted that "Yoni genuinely believe[d] he [was] a pacifist," but that despite this genuine belief, the committee found him not to be so, due, among other factors, to the fact that he had stated he would have fought the Nazis in World War II. The committee chair also testified that the committee did not have any stated regulations. This testimony led the court to ask the military authorities to grant Ben Artzi a fourth hearing, this time with a civilian philosopher as one of the members.

On August 10th the court heard another military officer, the Head of the Personnel Planning Unit, testify as to the "lighter service" options he had offered to Ben Artzi - offers which Ben Artzi had

104. The Ben Artzi case, supra note 98. 
declined. Later on the same day, the defense requested that the court summon Avi Sagi, a philosophy professor at Bar Ilan University, and the first civilian to be a member of the conscience committee. The defense wanted Sagi to testify because he had given an interview that was critical of the Committee's proceedings in the newspaper $\mathrm{Ha}$ 'aretz.. This petition stemmed from a Sagi's request not to be summoned as a defense witness against the committee in which he had served. The court granted the request, allowing the defense to summon Sagi as a defense witness, but the defense chose not to do so.

At the same meeting mentioned above, the court asked the personnel unit to reconsider hearing Ben Artzi's case for the fourth time. This request was made mostly because of Colonel Simchi's testimony, which stated the committee thought Ben Artzi to be genuine in his paficist beliefs. The personnel unit took several days to consider its position then rejected the court's request. The trial continued, and the parties' oral summations were heard on October 9th.

In its November 12th verdict, the court acknowledged flaws in the Committee's proceedings. It stated its belief that Ben Artzi was, indeed, a pacifist. The court even repeated its request for the Conscience Committee to hear Ben Artzi's case once more. However, it still stated that Ben Artzi should have obeyed the order to report for duty and convicted him. The defense attorney expressed satisfaction with the "partial victory."

While waiting for the sentence, Ben Artzi appeared before the committee for the fourth time. The committee decided to release him from service, but without admitting it had been wrong at denying him pacifist status. The basis for the decision was that Ben Artzi was selfish and would not make any useful contribution to the army. During the committee hearings and in newspaper interviews before the sentence, Ben Arzti did not express any wish to volunteer for some sort of alternative service. He wanted only to continue his studies at the university.

This attitude deviated from the "customary" conscientious objectors' readiness to engage in non-military voluntary activities, and infuriated the court as well as the committee. This was mentioned rather negatively in the sentence given on April 24th, Ben Artzi was sentenced to two months imprisonment and a fine, which, if unpaid, would result in two more months of imprisonment. The Ben Artzi 
family reported in an email to its supporters that Ben Artzi did not intend to pay the fine.

Ben Artzi's appeal of his conviction and sentence was heard before an unusual set of five judges - all of them were generals by rank. While the court treated the appellant with dignity and showed a willingness to discuss literary and philosophical themes it ended up denying the appeal.

\section{Flexibility and Legitimacy}

As the stories of the two cases demonstrate, the policies and practices toward the objectors resemble an exciting game of chess, with the defendants and their representatives as articulate and resourceful opponents who respond to the court's strategies with counterstrategies. The court was willing to allow the objectors in both cases significant flexibility in their attire and demeanor in court, as well as in summoning military personnel as hostile witnesses. In addition, the court is willing to assimilate extra-legal content into the hearings. The defendants' dissenting ideologies are heard at length, and the court even delves into their personal biographies to seek the origins of said ideologies. The following sections in part IV, which provide a reading of the narratives and ideas in the verdicts, examine the extent to which this leeway is given in the final decisions.

\section{LEgAL AND EXTRA-LEgal DisCouRSE IN CONSCIENTIOUS OBJECTOR VERDICTS}

\section{A. Defining the Problem: Highlighting Danger, Downplaying Controversy}

The court's notion of the offenses in both trials is constructed through the set of narratives surrounding the ethos of compulsory and egalitarian military. These narratives are the source of the court's knowledge about the severity and dangers presented by the offense.

Politically motivated conscientious objection is presented as ideological crime that constitutes a direct challenge to the law's validity. The dissenters' arguments might persuade others and break down the ideological-legal fabric on which service is based: 
This is ideological or political crime, and it is more severe and dangerous than regular criminal activity stemming from a wish for personal benefit...not only do they disobey the law, they renounce its compulsory power. They might be imitated by others, enjoy the support of people and public institutions, which hinders an egalitarian enforcement of law, and might gather around them a large public, who might be prepared to exhibit violence behavior to the point of mutiny and rebellion against the authorized government, that is, democratic society. ${ }^{105}$

The patriotic aspect of the duty of military service is undermined by the ambiguity created by objection and the public debate surrounding it. Importing political conflict into the military arena is seen in a negative light due to "the essence of military service and its connection to life risks; the security situation of the state and the need for personnel to execute military tasks."

The risks embedded in a legalization of conscientious objection constitute a challenge to both military and egalitarian considerations. Based on the legal principle of universalism, any right provided for the defendants must also be provided for everyone else. This theoretical broadening of the group receiving the rights leads the court to fear the following scenario:

It is not necessary to prove that acknowledging [the rights of] selective objectors might import the severe ideological-political conflict in the public about the righteousness of the government's actions in the territories into the arena of military draft, the duty to serve, and perhaps even into the army...[and subsequently] split the army into those who are willing to enlist in an army which engages in certain actions, and

105 Supra note 74 , at 67.

106. Compare this enterprise to Simon's account of the Warren Committee's fascination with Lee Harvey Oswald's childhood biography: Simon, supra note 14, at 91. 
those who are willing to enlist in an army which engages in other actions. The path from here to a split of the nation to several nations is not so far, and there is no need for experts to prove it. ${ }^{107}$

One topic that remains unelaborated, though by no means ignored, is the issue of military ethics. The court knowingly and ostensibly refused to engage in a discussion as to the righteousness of the defendants' opinions. It chose to decide the case based on the premise that these positions are subjective. However, the verdicts tread on thin ice in their treatment of the defendants' perspectives. In the Ben Artzi case the defendant claimed that from his pacifist perspective the order to enlist in the army was "clearly and obviously illegal." The court rejected this claim relying on the Supreme Court order to allow the draft. The fact that another judicial authority intervened suggests a set of circumstances where enlistment would not "clearly and obviously" violate legality:

Even if the test [for a 'clearly and obviously illegal' command] were subjective, we still thought that the defendant would have to obey the command. Since the Israeli Supreme Court ordered the defendant to enlist and begin his service... a legal obligation [to so do] was imposed on the defendant. Surely it cannot be said that an order to obey and order under these circumstances is an action which is clearly and obviously (even to the defendant) illegal. ${ }^{108}$

The court faces an even more difficult situation in "the five" case, where the defendants questioned the legality of the army's involvement in the territories. The solution implemented by the court

107. MaX Weber, The Methodology of the Social Sciences (Edward Shils, ed., The Free Press 1949).

108. The categories used by the court do not map neatly onto those defined by Rawls; their "legal" version makes them mutually exclusive for the purpose of classification. In fact, the categories resemble more a classification unquoted by the court, made by LINN, supra note 41 following Cohen, supra note 7, between "personal" and "political" motivations. 
quoted a significant number of Supreme Court decisions authorizing military activities in the territories, and then stated that despite these quotes they would not take a stand in the matter:

This court is not, of course, the forum to examine the legality of this or that governmental action, and it certainly is not the proper place to examine the government's policy toward the held territories and their local inhabitants or the implications of this policy on the state's citizens. ${ }^{109}$ We state immediately, our quotation of the essence of these sources [legitimizing the army's activity in the territories] was meant only to test the credibility of the defendants' claims that their conscience tells them to act like they did... the court does not intend, is not authorized and is even unable to express any opinion about these claims. ${ }^{110}$

\section{B. Understanding the Offenders: "Good" and "Bad" Moral Dissent}

As explained in sections I.C, II.A and II.B, both trials presented the court with ideologically motivated, resourceful and articulate defendants who were prepared to stand trial for their. The legal system's response to this unique population is evident not only from its reluctance to reach the stage of military criminal trials, but also from the court verdicts. Though in most instances the court refers to the objectors as "the defendants." it also uses their first names, particularly in the first thirty pages of the "five" case. It also mistakenly refers to one of the "five" as a "witness," rather than a "defendant."

The uniqueness of conscientious objection cases may therefore partly account for the court's interest in learning about the objectors' personalities and motivations. However, the court's endeavors to understand the defendants in these cases may also stem from the importance it ascribes to their ideologies, the driving force behind the

109. Supra note 74 , at 75.

110. Id. at 18 . 
act of conscientious objection. As mentioned above, it is obvious that the court takes these defendants very seriously; it seeks to learn the "etiology of ideology" behind the defendants' actions. As the court poetically phrases it in the Ben Artzi case, it is interested in "the evolutionary history of his ideological pattern of thinking... where and when his thought bloomed with the seeds of thought and pacifist belief.",111

Indeed, both verdicts focus to a great extent on the defendants and their personal histories. In the "five" trial, the court engages in meticulous retelling of each and every defendant's personal story, including their childhoods, the political atmosphere in their homes and families, their political experiences and activities through middleschool and high-school, and their insights on the situation developed both before the draft and following incarceration for refusing it. The verdict contains accounts of an Israeli-Palestinian science summer camp one of the defendants had participated in while in high school, as well as the defendants involvement with Palestinian aid organizations as students. ${ }^{12}$ It also contains quotes from the defendants themselves about their beliefs. ${ }^{113}$

The evidence cited in the Ben Artzi verdict includes his arguments with teachers over school trips involving entrance to the territories, his mother's account of his refusal to wear a "kippa" in a military cemetery, extensive testimony by the defendant's sister (defined by the prosecutor as "an expert witness [whose expertise is] Yoni"), and references to the opinions of his parents, grandfather, schoolteachers, and friends about the nature of his objection.

A narrow reading of the court's role questions the necessity for such information. For the purposes of conviction the only necessary information is whether the defendants refused to be drafted and whether they have received exemption as pacifists. (None of them did: the "five" because they never claimed to be pacifists, and Ben Artzi because the committee did not grant him exemption despite his claim to be one). In fact, these are the issues by which the two cases were

\section{Ibid. at 90 .}

112. Ben Artzi case, at 32.

113. Ben Artzi case, at 8 . 
eventually decided. "The five" were not pacifists, and therefore, were not eligible to be discharged by the conscience committee. Ben- Artzi, despite his pacifism, was not legally discharged by the committee whose actions, though faulty, did not render its decision void. The court, however, sets off on an enterprise to understand the psychological and historical emergence of the defendants as autonomous adult agents with opinions. ${ }^{114}$

This enterprise does not lead the court to draw a comprehensive and complex portrait of the defendants, but it does lead to the much more legalistic and prosaic task of classifying them into Weberian "ideal types" 115 according to their motivation. This classification process serves the court not only in its decision to convict in both cases, but also in creating a rhetoric of who should be seen more and less favorably by the system. For the purpose of this classification, the court seeks to reduce the opinions and actions of each of the defendants into monolithic, mutually-exclusive categories based on their main motive: pacifism (termed "total conscientious objection"), personal discomfort stemming from political dissent ("selective conscientious objection"), or a will to bring about a change in public opinion and possibly to convince others to object to serve ("civil disobedience").

In "the five" case, the court emphasizes the distinction between the second and third of these categories: selective (political) objectors whose motive is personal and those whose intentions are to cause political change. These categories are a simplification of the philosophical categories of "civil disobedience" and "conscientious objection."116 While the current legal order does not distinguish between the two for the purpose of the legal/illegal distinction, the cour might have seen this categorization as an answer to the defense's argument for acknowledging objection on political, as well as pacifist,

114. Compare this enterprise to Simon's account of the Warren Committee's fascination with Lee Harvey Oswald's childhood biography: Simon, supra note 14.

115. WEBER, supra at note 114 .

116. The categories used by the court do not map neatly onto those defined by Rawls; their "legal" version makes them mutually exclusive for the purpose of classification. In fact, the categories resemble more a classification unquoted by the court, made by LINN, supra note 41 following COHEN, supra note 7, between "personal" and "political" motivations. 
grounds. The court does not give the defense any hope that such rights might be granted, but even within the group of political objectors, who do not enjoy the potential of discharge from service, it renders some to be more positive and less harmful than others. The "good" objector in this categorization is a good-willed, sensitive individual who does not seek to change the world, but merely to remove himself from a morally detrimental environment. This objector can be described as a positive character and is expected by the court to exhibit altruistic, highly moral behavior in all respects except willingness to serve in the army. The "bad" objectors, by contrast, do not conform to this ideal picture. They are "political" objectors, social agitators who seek political change.

The court finds "the five" (as a group) to fit in the second category. In the verdict, as well as in the sentence and in previous decisions regarding their imprisonment terms, the "five" are described as political changers and revolutionists. This image is created through an analysis of "the five's" political activities, particularly as highschool seniors. Setting aside the question of jurisdiction over motives and actions committed by the defendant as civilians, the interesting notion here is that of monolithic, mutually-exclusive motives for action. According to the verdict, one can be either a conscientious objector, or a political advocate of civil disobedience but not both. The court does pay some homage to Joseph Raz, quoting him to say that it is possible to be "over-determined" in motivation, and therefore to be both at the same time, but it prefers its own theory of personality:

We found that we are close to the opinion... according to which, although the possibility of duality in motives is possible, it is, in general, a theoretical and distant possibility. We thought that the main motive hiding behind the actions of the defendants before us, considering the totality of circumstances surrounding their actions, is the will to cause a political change, that is, to bring about a change in public opinion and the governmental policy. We doubt whether the conscientious motive, in itself, is enough to be a basis to the defendants' refusal, based on the totality of the things they said. Yet, we are ready to avoid stating unambiguously, that the civil disobedience motive is the only one moving the defendants, and to assume, that it is 
also a motive of conscientious objection which moves them, perhaps even as a sufficient motive, to commit the act of refusal. ${ }^{117}$

This distinction is then abandoned for the sake of the traditional legal distinction between pacifists and political objectors. For reasons of manageability the court created a flawed and uneasy equivalence between the distinction "conscientious objection/civil disobedience" and the distinction pacifism/political dissent. This was justified by the need for visible, workable definitions, and even quoted Chief Justice Barak as to the value of clear definitions at the expense of accurate but complex ones.

Interestingly, the "good/bad" distinction has nothing to do with actual goodness or honesty. In the verdict, one of the judges describes the defendants as "positive and value-minded young men in their essence," 118 praise which is of little assistance as punishment is imposed. Similarly, the court is at pains to clarify that the virtue of honesty avails nothing in the legal/illegal distinction:

There is no point to plant within the petitioners' hearts the illusion, as if the committee might exempt them from service if it thinks they are honest in what they say, and it would have been right to clarify to them immediately, that their refusal to serve, driven by motives of said kind does not, according to current policy, award an exemption from service. ${ }^{119}$

Ironically, it is precisely the defendants' honesty about their history and opinions which provided the court with the information that classifies them as "bad" objectors. Less honest defendants would be better off by presenting themselves as pacifists and cloaking their political agendas. The catch is, of course, that conscientious objection is by definition an offense that stems from honesty and personal integrity.

117. Supra note 74 , at 75.

118. Id. at 18 .

119. Id. at 90 . 
Thus, the defendants' own motives are used by the court to justify their convictions.

The Ben Artzi case presents more complexity for the enterprise of classification, as he defies the court's distinction between "good" and "bad" conscientious objectors in more than one way. He is found to be a genuine pacifist (despite the committee's findings), but this is hard for the court to reconcile with his other traits: a radical left-wing political view and an inability to conform to coercive institutions. Ben Artzi also refuses to redeem himself in the court's eyes by proclaiming that contrary to the "good" objector's stereotype, he will not volunteer to do community service in civilian life. ${ }^{120}$

The court tries to make sense of Ben Artzi's enigmatic personality by collapsing all these complexities and perspective onto a one-dimensional personality model. Instead of accounting for the possibility that a person's views on conflict resolution methods can be detached from his views on the Israeli-Palestinian conflict and his ability to conform, they undo the contradictions by negating their possibility, or, in the very least, making such a contradiction unlikely. The judges state that "lack of ability to adjust to a mandatory framework" and pacifism are linked: a pacifist person is a minority in Israel and cannot adjust to the framework anyway because of his unpopular beliefs.

The connection between the two traits is so strong that it cannot, supposedly, be deciphered. It is, as the court describes it, a chicken and egg problem: "Is the inability to adjust to the military framework a consequence of the pacifist belief, or perhaps the pacifist belief is the cause [sic] of the inability to adjust to, or to accept, the existence of a military framework, whose goals are defined the way they are defined, and whose means are the way they are?!"121 A similar logical ploy collapses pacifism and left-wing political views into the same category. "The defendant distinguished... between the pacifist belief and the political view (though it is clear that a pacifistic view will be difficult to reconcile with a different political view)." 122 Thus, Ben Artzi's

120. Supra note 104 , at 11 .

121. Id. at 32 .

122. Id. at 33 . 
personality is reconstructed onto a simplified model, allowing for his classification as a "bad" conscientious objector and leading to his conviction despite his declaration that he is a pacifist. It also allows for a negative representation of him in the sentence, which echoes the committee's original impression of him, while acknowledging that he is a genuine pacifist.

\section{Using Knowledge: Legal and Extra-Legal Sources for Perceiving the Problem}

What are the epistemological sources used by the court to construct these images of the offense and the offenders? A careful reading of the verdicts uncovers a self-referential pattern. The court is exposed to political and philosophical narratives, but it eventually turns to internal legal sources as its preferred source of knowledge of conscientious objection. However, the resourcefulness of the defendants and their representatives does have an influence on the way the legal sources are applied to the problem.

As shown before, the court does not perceive the offenders to be regular criminal defendants and even hesitates to refer to them as such. This avoidance of criminal law as the relevant legal discipline for the case, which is after all a criminal case, is discernible from the way the verdicts avoid discussing the elements of actus reus and mens rea. In fact, the main lexicon the court used in the verdicts is the constitutional language of rights, and the verdict uses this framework to identify the questions it wishes to address and answer. In the Ben Artzi case the court merely wants to identify how much of the defendant's refusal is political, and thus dangerous, and how much of it is owed to a nonpolitical, low-profile, pacifist perspective that poses fewer problems for the system: 1) What is the weight of the right to conscience in Israeli law? 2) Was the defendant's draft legal and valid in respect to the fallacies in the committee's work - what is the normative meaning of the committee's decision? 3) Does the defendant enjoy a criminal defense barring his criminal conviction in the offense he has allegedly committed? ${ }^{123}$

123. Id. at 8 . 
The parties' perspectives are also presented in legalconstitutional terms:

Indeed, ostensibly, it seems that each one of the parties is in a completely different plane in their arguments. The prosecutor is in the plane of giving validity to the draft order... and the defense attorney, he is in the plane of examining the criminal defenses available to the defendant which stem from the power of the constitutional right to act according to conscience. ${ }^{124}$

Similarly, in the "five" case, the agenda is framed in constitutional terms and dressed in the philosophical garments of conscientious objection versus civil disobedience.

A. Have the defendants in their testimonies managed to convince that their refusal to serve is built on moral-ideological foundations?

B. Do the reasons for their refusal constitute conscientious objection, civil disobedience, or a mixture of the two?

C. What is the implication of deciding this question - in case we are dealing with acts of civil disobedience or mixed acts of civil disobedience and conscientious objection - do the defendants then enjoy a defense from criminal conviction?

D. Assuming the defendant's refusal is based on a conscientious cause (alone or in addition to other causes), does freedom of conscience enjoy the defense that basic rights enjoy?

E. And if so - is there an existing law, that allows such infringement in these circumstances? What are the opposing interests that might justify a violation of the right to free conscience? Were such interests proved in the case before us? Has the balancing between them lead to the finding, that the violation of the right to free conscience is in a measure that does not exceed the necessary? ${ }^{125}$

124. Id.

125. Supra note 74 , at 2 . 
The main two branches of knowledge relied upon in the verdicts to answer these constitutional questions are the judicial art of legal reasoning (the ability to weigh considerations and interpret laws correctly) and political philosophy. There are two interesting aspects of this choice of disciplines. Firstly, the judges do not see any necessity to get insights from social science or empirical research. This in itself is not news; the novelty lies in the fact that the "five" verdict explicitly deals with the question of empirical knowledge and rejects its relevance. Prompted by the defense's claim, according to which no empirical evidence was admitted to show the potential danger to the Israeli state should the defendants' acts be legalized, the court states:

We are speaking of matters that are known to everyone, things that were claimed again and again in front of the different courts, and adopted by them. Indeed, the Supreme Court, sitting as High Court of Justice, stated the main part of these doubts and dangers, and adopted them as a cause and a reason to avoid assisting the petitioners, who had addressed it asking to legally recognize their refusal to perform military service. ${ }^{126}$

In this manner court rulings, by the very fact of their existence on paper, become empirical evidence. Court opinions, by becoming part of the precedential historical reservoir, become facts. The court goes much further by referring to legal and philosophical articles submitted by the prosecutor as a "Brandeis Brief." They describe its contents as follows:

To the findings file, which was presented to the court, were added, in addition to the Supreme Court's verdicts and those of other (military) courts, articles and letters, which were written by jurists, philosophers and thinkers from the fields of society and humanities. ${ }^{127}$

126. Id. at 88 .

127. Id. at 86 . 
The "thinkers in fields of society and humanities" mentioned are six scholars in the fields of jurisprudence and philosophy. It is unclear what the "fields of society" are. In any case, the court is obviously of the opinion that Supreme Court precedents and doctrinal academic treatises will supply it with all the empirical information it needs about the risks of conscientious objection.

The discipline of philosophy seems to enjoy a more favored status in the eyes of the court, but the legal adoption of philosophical concepts happens in accordance with law's internal terms. Both the "five" and the Ben Artzi verdicts are filled with quotes from legal philosophers, but these are not used to achieve any material goals. The court uses the terms "civil disobedience" and "conscientious objection," both staples of political philosophy, but never dives into the conceptualization behind them. Rather, it chooses to use a crude distinction between "total objectors" to the military in general and "specific objectors" to specific military actions, as supposedly representing the finer distinction suggested by philosophy. As explained above, this simplification is justified by its workability. It seems that the homage paid to philosophy is mainly symbolic, and when the court needs information it prefers to be assisted by juridical wisdom. The court's reliance on previous verdicts is valid because, according to "the five" verdict, the different verdicts, fruit of many years of thought, wisdom and life experience of judges with and without legal education, comprise within them real evidentiary power, as far as the interests, the risks and the dangers we have discussed above. ${ }^{128}$

As to the court's own juridical reasoning and consciousness, this is described as common knowledge which is within the court's permissible room for assumption. The verdict states that the national security situation is within judicial knowledge, and so is the risk to soldiers in the service that the assumption is "recognizing selective conscientious objection constitutes a bypass of the democratic process and an unacceptable interference in it." This is a phenomenon that, if widened, will lead to a great divide of the Israeli public (another judicial assumption). As further justification for assuming all these things, and for not accepting any data to suggest empirical answers for them, the court compares these cases to "the appraisal of the risk from a defendant or suspect, whose arrest is being requested based on the

128. Id. at 88 . 
possibility that he might endanger the public."129 The court disregards the social and political differences between the case at hand and the example provided.

\section{Achieving Goals: Punishing the Offenders and Obtaining Legitimacy}

Applying the court's perception of conscientious objection to the offenses and the offenders is aimed at achieving both ostensible and latent goals, both of which interact with the legal and extra-legal sources of knowledge used by the court.

The ostensible goal of the court in conscientious objector cases is achieving the end of punishment, primarily retribution and deterrence of future potential objectors. In the sentences, the court mentions the ends of punishment, focusing primarily on deterrence, but mentioning retribution as an additional reason for harsh punishment. As shown earlier, the compulsory and egalitarian military ethos that conscientious objectors resist builds on a patriotic emphasis on the necessity for defense and social unity. The verdicts, therefore, emphasize general deterrence as an important aim: "This reason is a clear justification to punish defendants harshly so that the multitudes to whom the defendants' call was addressed will see, and fear, and understand, that the price for an act of refusal is painful, harsh punishment." 130

This rationale is particularly important due to the classification of "the five" as "bad" objectors, whose aim is to influence others, but it also leads to the court's rejection of personal deterrence as an appropriate end of punishment in the case. The defense attorney is quoted saying that such consideration, in light of the ideological motive of the offenders, makes deterrence not only unnecessary, but unconstitutional. The court seems to partly agree, and rejects personal deterrence claiming it would make no sense in light of the defendants' strong conviction. ${ }^{13}$

129. Id. at 89 .

130. Supra note 74 , at 18.

131. Id. at 17 . 
The court also states, in both cases, its disapproval of the offenders and uses their classification as "bad" objectors to justify punishment on the basis of retribution. Most of "the five" verdict, as shown earlier, uses negative language to describe the defendants and justify harsh punishment. Retribution, or desert, demands harsh punishment. Though, the judges are careful to add that "the army's policy is to be harsh on those who are already in service and decide to refuse (like between deserters from service and draft evaders)."132 Part of the retributive consideration in the Ben Artzi case is the court's dislike of his unwillingness to participate in alternative service. ${ }^{133}$

The court's discussion of rehabilitation is particularly insightful. The sentence renders this end of punishment to be irrelevant for "the five" conscientious objectors because they were not moved to act the way they did out of lower social status, falling to poverty or drug abuse; they did not do what they did as an act stemming from loss of values. Therefore, and since the defendants have stressed, as mentioned above, that they do not see themselves serving in the army in the future, this consideration does not have weight in sentencing them. ${ }^{134}$

In the court's mind, therefore, rehabilitation is not merely a general, amorphous consideration; it is something designed and aimed at the underclass, rather than the affluent and idealistic defendants in conscientious objection cases. This paragraph shows that the social resources available to these particular offenders are in the court's mind even though they do not explicitly mention this in the verdicts themselves.

The court recognizes that it works side by side with other military institutions, mainly the Conscience Committee, in its dealings with conscientious objection. The alliance between the court and the committee, which occupies center stage in the Ben Artzi case, is an uneasy one. Although the court defends the committee from the defense's attacks on its processes and capability, it does not avoid thinly veiled criticism of the procedure. Similarly, the court is explicitly

132. Id. at 14 .

133. Supra note 104 , at 10.

134. Supra note 74 , at 18. 
uncomfortable with the embarrassment laid at its door by the committee's chair when he testified that Ben Artzi "genuinely thinks he is a pacifist" but is not one (see section II.B). The Court comments, "[w]e cannot imagine, that this part (the defendant's honesty) escaped the testimony of the senior officer, but any reference to it was absent from his decision." 135

In light of these ostensible goals, which seem to require harsh sentences, how does the court justify its procedural flexibility in the conscientious objector trials and its readiness to let the defendants 'voice' their political opinions and biographies? The answer lies in the verdict's latent agenda, which is aimed at obtaining legitimacy for its decision. In order to perpetuate the ethos of compulsory and egalitarian service, the court needs to reject, epistemologically, the objectors' position. However, in order for such a decision to be validated by the verdict's audience - the defendants, the media, the Supreme Court and academic scholars - the court must show that the decision was reached in compliance with every possible aspect of judicial fairness. This requires an absolute lack of bias, particularly of the political persuasion, procedural flexibility, and a willingness to award the defendants ample opportunities to state their case.

How does the court display its fairness? As mentioned in part II, the hearings themselves are an important contribution by being procedurally flexible and substantively inclusive. The verdicts, too, are at pains to show the court as a legitimate, unbiased institution. In both verdicts, ample space was provided for the presentation of the defense position and compliments are given to the legal representatives of both parties. The court cleverly dissociates itself from the political issues raised in the case by presenting the defendants' political criticism as direct quotations rather than paraphrasing it. These methods present the court as playing by the rules of the game in a very forgiving manner, and still reaching the necessary conclusion. ${ }^{136}$

\section{Supra note 104 , at 77.}

136. Compare this to similar mechanisms of obtaining legitimacy, such as Hay's observation of the role of mercy and procedure in legitimizing the usage of death penalty in Early Modem England, in Hay, supra note 19. Also see: Alan Stone, The Place of Law in the Marxian Structure/Superstructure Archetype, 19 LAW AND SOC'Y REV. 39 (1985). 


\section{Conclusion: LaW's Response to Political Dissent: SimPLiFICATION, CATEgORIZATION, AND SELF-REFERENCE}

The court, as seen in the cases discussed in this article, works to make sense of complex people and unclear situations by creating clear standards and stereotypes to which people must adhere.

This quality of judicial decision-making is not endemic to judicial decisions regarding conscientious objection. The use of "masks" to collapse people and situations into easy to handle categories is extensively discussed by John Noonan. ${ }^{137}$ He highlights the judicial tendency to prefer "masks" and rules over persons. Similarly, feminist socio-legal research has studied the court's response to female defendants who do not conform to feminine, family-centered stereotypes. ${ }^{138}$ As shown in this literature, the court seeks to reduce human complexity into manageable compartments. People are expected to be logical, coherent, and to have specified and distinctive motivations for their actions.

This is the case with the conscientious objectors in the two verdicts. The court's understanding of the nature of the problem creates "good" and "bad" personalities for the defendants, and the verdicts adhere to these categorizations to make sense out of the situations and the people involved.

What is unique to the population of conscientious objectors is the content of the legal categories designed address their actions. According to the court the key to being a "good" conscientious objector is to be less politicized, less controversial, and more personable and less public. The "good" conscientious objector is someone who has a general, well-developed theory of personal morality. A pacifist conforms to what the court sees as "pacifist behavior," a pleasant, nonconfrontational person who cares more about personal ideals on social welfare than about public activism. A "bad" conscientious objectôr is

137. John T. NoOnan, Persons ant Masks of the Law: Cardozo, Holmes, JEFFERSON, AND WYTHE AS MAKERS OF THE MASKS (Farrar, Straus \& Giroux 1976).

138. Bryna Bogoch and Rachel Don-Yichya, GENDER AND LAW: DISCRIMINATION AGAINST WOMEN IN ISRaEli COURTS (1999); KATHLEEN DALY, GENDER, CRIME AND PUNISHMENT (Yale University Press 1994); Frances Heidensohn \& Marisa Silvestri, WOMEN AND CRIME (New York University Press 1995). 
someone who uses his action to influence others, or someone who defies the positive stereotypes associated with the "good" objector. For these people, the court borrows, and modifies, the philosophical concept of civil disobedience.

The court establishes binary monolithic truths by forcing the complexity of human nature into a framework, and even when the presence of more than one motive for behavior is evident, the question is which motive is the dominant one. These motives are then applied by the court without the aid of any empirical extrapolation tools to make judgment about empirical risks and chances for limiting rights. For conscientious objectors, the court conducts an uneasy and inaccurate dialogue with philosophy, only to reinforce the usage of its own instant, simple-to-apply categorization. Despite these references to external disciplines and professional expertise, the court eventually looks into itself, and into doctrinal law, to create these classification tools. They trust their own judicial experience to guide it in the right way.

In doing so the court treads a thin line between legal formalism - the adherence to Weberian categorization of cases - and openness to the extra-legal issues presented by the objectors. As explained in section III.D, this course of action serves the court's latent agenda of obtaining legitimacy. However, the court is not the only party gaining from this arrangement. The defendants in both cases are, based on their ideological eloquence and social milieu, people who have powerful resources at their disposal. Moreover, they are people who chose the legal arena to make a political point. They knowingly undertake the risk of being found guilty and suffering the consequences. While in the narrow sense of legal outcome the objectors lose their cases, the court's willingness to provide the defendants a platform to express their political dissent may translate to benefits in the broad arena of public opinion. ${ }^{139}$ Although this does not suggest a conspiratorial "bargain" between the court and the objectors; it certainly shows how choices that shape the form of a trial may produce a win-win situation, rather than the more traditional perception of criminal justice as an adversarial, zero-sum game.

A final comment pertains to the usefulness of using an examination of knowledge structures, rather than merely concepts of

139. Indeed, the objectors enjoyed a wide, and to a great extent favorable, media coverage of their trials: Aviram, supra note 103. 
right and wrong, to analyze situations like the conscientious objection trials. As resistance to governmental actions in general, and to military actions in particular, continue to occupy legal systems and scholarship, the discursive analytical framework used here may be useful for understanding law's interaction with the complex extra-legal factors which shape such phenomena. Before "taking sides" in the political controversy, it is useful to observe how the positions of such "sides" are epistemologically shaped, and what brings about our perceptions of the problems in question. 